\title{
J. D. Salinger Studies in North America and in China*
}

\author{
Yang Gao \\ School of Foreign Studies \\ Hefei University of Technology \\ Hefei, China
}

\begin{abstract}
J. D. Salinger and his works have received much interest and popularity among readers and critics during the past sixty years. This paper aims to sort out the critical studies of Salinger's works in North America and in China according to different periods divided and such a conclusion can thus be made, that is, Salinger studies have achieved and progressed a lot in both America and China, with more literary theories employed and increasing depth reached, but there are still some aspects that can be done better on, including the study of his uncollected short stories, Salinger's biography and epistle study and the influences of eastern thoughts on Salinger's writing.
\end{abstract}

\section{Keywords-J.D.Salinger; studies; North America; China}

\section{INTRODUCTION}

On the night of January 27, 2010, J. D. Salinger left this world forever, which brought this recluse back into the world's horizon once again; improvised video clips mushroomed in the Internet during the following days, in which people who ever loved him were reading Holden or Franny loudly to mourn this genius writer. Yet Salinger is anything but a prolific writer; he even did not publish a single work during the last forty years of his life. So far, works that can be identified as his creation amount to 44, which include The Catcher in the Rye (1951), his always best-seller, 13 stories that are respectively collected in Nine Stories (1953), Franny and Zooey (1961), and Raise High the Roof-Beam, Carpenters and Seymour: An Introduction (1963), 22 published but unanthologized short stories which were collected in 1974 by his fans into two volumes of pamphlets and thus spread in the Internet now: The Complete Uncollected Short Stories of J.D. Salinger (vol. 1: Twentyone Stories and vol. 2: Hapworth 16, 1924), and at last, 7 unpublished works, namely, The Ocean Full of Bowling Balls, The Last and Best of the Peter Pans, Two Lonely Men, The Children's Echelon, The Magic Foxhole, Birthday Boy and Paula, presumably finished between 1941 and 1945. After the publication of Hapworth 16, 1924 in 1965, there has been no more news about his literary creation. Salinger's brilliance, as well as his life as a mystery, arouses much interest and attention among his readers and critics. Since the 1950 s, the so-called "Salinger fever" lasted for four decades

*Supported by the Key Project of Humanities and Social Sciences in Colleges and Universities of Anhui, China: "Taoism in J. D. Salinger's Works" (Project No.:SK2017A0060) around the world till the end of the 90s. In the 1980s, with the introduction of The Catcher in the Rye into China by its translator Mr. Shi Xianrong, Salinger's works made waves in this ancient Asian country and excited numerous Chinese readers and critics as a result. Therefore, this paper is going to sum up J. D. Salinger studies in North America and in China with the intention that a bird view could thus be offered to those people who love him, whether as a fan or as a researcher.

\section{J. D. SALINGER STUdIES IN NORTH AMERICA}

Salinger Studies in North America officially started from 1951, the year when The Catcher in the Rye got published in the U.S., in spite the fact that his writing career actually began earlier in the 1930s. Then the 80 s and the $90 \mathrm{~s}$ witnessed a surge of Salinger studies and till now his works still catch a certain level of academic attention. In terms of texts studied, both Salinger's novel and his short stories are included. What's more, Salinger studies in North America also vary in theory and methodology. Generally speaking, such a trend has already unfolded, that is, personal comments have gradually been replaced by academic criticism; the mainstream type of study results transfers from journal articles to dissertations because of the participation of many younger scholars; and the range of study tends to move from a single work or a single character in his work to more complicated studies which either make a comparative study of Salinger and other writers or categorize his writings into a certain social period or under a certain theme for a more comprehensive research. On the whole, Salinger studies in North America can be chronologically divided into such four phases as follow:

\section{A. From 1951 to 1965}

The core of Salinger studies in the initial period was his masterpiece The Catcher in the Rye, most of which were personal interpretations of or comments on this novel's theme, the protagonist or its language, with its literary value failing to be truly discovered.

Firstly, on the theme of this novel, Arthur Heiserman and James E. Miller argued that the whole story was nothing but a sort of "quest" through which the hero experienced growing pains and seeking for love [1]. Henry Seidel Canby deemed it as an adolescent novel, praising it for reaching 
deep into reality [qtd. in 2]. Also, many a critic looked at the moral dimension of the novel and affirmed the importance of love in it.

Character analysis was another heated subject during this time. Holden the protagonist was said by many critics and reviewers to be an idealist, an innocent boy tragically frustrated by the harsh and ugly adult world. Ihab Hassan regarded him as a quixotic gesture [3]. Jonathan Baumbach called him "a saint"- "the protector and savior of innocence" [4]. However, Peter J. Seng judged Holden as "in some sense a tragic figure" [5], who cannot accept the world as it is. Comparative study was strongly welcomed by book reviewers to analyze the protagonist during this time. Holden was compared with Huck Finn by Heiserman and Miller, Edgar Branch and so on, in view that the two boys are quite similar in their experiences and talking habits. What's more, Holden was also compared with Gatsby, Rabbit, and Yossarian for the qualities they share, like their dissatisfaction with the society and some dreamlike ideal they have. Other works like The Lord of Flies, The Waste Land, Odyssey and A Clockwork Orange were also once made comparison with The Catcher in the Rye by many critics [6].

Thirdly, symbolism and language were assembled into those critics' study range, too. Critics tried to interpret those images repetitiously appearing in the novel, such as ducks, museums, the red hunting hat, the record, the carrousel and even the protagonist's wandering. Colloquial style, dirty words, exaggeration and repetition constitute major characteristics of this novel's language. Costello surveyed Holden's diction and found the language in the novel authentic, essential to Holden's characterization, and an important "part of an artistic achievement" [7].

On the other hand, voices of disagreement in this period also sounded loud. Some critics doubted the worth of this novel and blamed it for its formlessness, loose plot, obscenity and profanity. For instance, Ernest Jones thought it "predictable and boring" as a whole [8] and Anne Goodman claimed, "the book as a whole is disappointing" [qtd. in 9].

\section{B. From 1965 to 1979}

The Catcher in the Rye kept its academic importance during this period as ever with the growth of its acceptance as well as the increase of new interpretative perspectives.

Comparative study still went on: Lilian Furst made a comparison between this novel and Dostoyevsk's Notes from Underground [10]; Gary A. Wiener compared it with Ken Kesey's One Flew over the Cuckoo's Nest, illustrating their similar comments on society [qtd. in 11]. At the same time, many new perspectives appeared. James Bryan wrote an article about the psychological structure of this novel in 1974 [12]. Carol and Richard Ohmann examined it from a Marxian perspective, arguing that the economic and social arrangements of capitalism should be taken into consideration in the study of The Catcher in the Rye [13]. Gerald Rosen analyzed the influence of Eastern thought and religion on the novel [14] and Tom Davis compared Holden to the Buddha, a selfless savior "willing to be born again into a world of sin and suffering in order that, through his many incarnations, he may help others struggling to find release from the wheel of birth and death" [qtd. in 15].

A remarkable change in this period was that study papers about Salinger's short stories began to rise, with the researches mainly centering on the following two aspects: one was the analysis of the critical characters in the Glass family, for instance, Samuel Irving Bellman analyzed the signs and reasons of Seymour's suicide [16], and Max F. Schulz argued that Buddy in Seymour: An Introduction is Salinger himself [17]; the other was the study of Salinger's religious thought revealed in his short stories, for example, Sumitra Paniker summarized the eastern thought in Teddy [18]; James Finn Cotter explained some Christian symbols in Salinger's short works [19] and Bernice \& Sanford Goldstein unveiled the quest of Franny, Buddy and Zooey for Epiphany as pious followers of Seymour [20].

\section{From 1980 to 1999}

The third period saw a great flourish in the study of The Catcher in the Rye, with more multifold angles involved and further depth shown. Psychoanalysis and political criticism could still be seen: the "Holden phenomenon," according to Huber, is a result of his deep-seated feelings of inferiority [qtd. in 21]. Nadel argued that Holden's speech reflects the pressure and contradictions prevalent in the Cold War society and that his personal struggle is analogous to the irreconcilable of guilt and innocence prevalent during the McCarthy era [qtd. in 22]. Although alienation and search for the father were still the main themes of this period, some post-modernistic features were put into interpretation. The emergence of new literary theories turned Salinger studies to new directions such as cultural criticism and gender study, and more and more attention was cast to "Zen Buddhism" contained in this novel.

At the same time, academic scholars did not give upon the study of Salinger's short stories, with character analysis and religious interpretation as the focal points, Anthony Kaufman believed that Teddy's tragedy is induced by the lack of love [23]; Sheila O'Hearn thought what Seymour represents is hope rather than hopelessness [24].

There were two new turns in this period: first, vertically seen, Salinger's researchers began to integrate his short stories with his novel so as to make a comprehensive and also a macro consideration of his works. For instance, Angela L. Goad explored the idea of "Zen" in Salinger's writings [25], while Eugene Dale Antonio elaborated the Taoist thought in Salinger's works [26]; the other turn was that more and more scholars brought Salinger's and other writers' works together into the discussion of a certain theme or the study of a certain time of literature development. Beverly Narod Hindin explored the death theme in modern and post-modern American literary works, on the basis of text analysis of The Catcher in the Rye, The Sound and the Fury, The Great Gatsby and A Farewell to Arms [27]. Jean Timberlake chose Salinger's De Daumier-Smith's Blue Period, For Esmé-With Love and Squalor and Franny and Zooey as well as other 11 short stories by different writers as 
texts and analyzed the conversion theme in American short stories [28].

\section{From 2000 till Now}

The so-called "Holden fever" has cooled down, but there are still many enthusiastic researchers keeping on their study. Narratology came out as a new theoretical perspective. Williams F. Rannals examined the narrative voice and the author's intention in The Catcher in the Rye [29]; Monika Gehlawat elaborated the author's intervention/disappearance and intertexuality in Franny and Zooey [30]. More importantly, the two new turns which came out during the third period have thrived in this period with more attention from young researchers. On the comprehensive study of Salinger's works, Eleanor Demler made an archetype analysis of Seymour, Sergeant X, Teddy, Holden and Franny [31]; Esra Kilicci made an existential interpretation of Holden, Sergeant X and Seymour [32]; Julia Eliane Judlin explored the traumatic effects of the WWII on Salinger's creation [33]. In the meanwhile, more horizontal studies have appeared during this time: Karen R. Tolchin found and analyzed the growing problems of American adolescent, with the works of Salinger, Philip Roth and Edith Wharton chosen as textual examples [34]; Thomas P. Durkin juxtaposed the works of Salinger, Ken Kesey and Jack Kerouac to analyze the theme of madness and the social construction of masculine in American literature [35]. What's more, Salinger's writing experiences has begun to be noticed and some scholars start to study the influences of Hemingway and Updike on Salinger's literary creation.

\section{SALINGER STUDIES IN CHINA}

Academic studies on Salinger's works took a quite late step in China; not until the 1980s did The Catcher in the Rye begin to be noticed. Generally speaking, Salinger studies in China mainly focus on The Catcher in the Rye and the research results before 2000 were far less prosperous than those in the recent 17 years, whether in terms of number or perspectives. What's more, other works of Salinger began to become appealing to Chinese scholars after the new millennium, which contributes to the more complete and comprehensive research of Salinger in China. Basically, Salinger studies in China can be divided into the following two phases:

\section{A. From 1980 to1999}

Like the initial stage of Salinger studies in America, the studies of Salinger in this period of China also centered on the analysis of the theme, characters and the language style of The Catcher in the Rye. As to the theme of this novel, some argued that it is a realistic novel to criticize American reality, with Li Zhengrong [36] as one of the representatives. Shi Xianrong, the first one to translate this novel into Chinese believed that it is a psychological masterpiece that shows the psychological dilemma of the Beat generation [qtd. in 37]. In addition, there were also different opinions on the analysis of Holden. The protagonist was regarded as a rebellious figure against American culture and society, or as a loafer and an outsider, or an idealist who is seeking a clean land. Other aspects like language, symbolism and narrative style were also to different degrees examined, although not as deep and far as the analysis made on the theme and the character. Hou Weirui thought this novel "takes a generalized record of the language habit of that generation of young men" [38]; Li Zhanzi concluded in detail the colloquial style of this novel's language [39]. In addition, some scholars also made psychoanalysis of the protagonist or make comparative studies of this novel with other ones: Luo Shiping believed that Holden suffers from some type of psychological disease [40]; Liu Jianbo compared Quentin in The Sound and the Fury with Holden [41]. As for other works of Salinger, the only one reviewed in this period was For Esmé. Esmé the heroine, according to Cao Shunrong, is "flat" in characterization [42].

\section{B. From 2000 till Now}

The Catcher in the Rye is still the focus but more literary theories are applied during this time, among which the one used the most frequently is deconstruction, such as Yan Zhijun [43]. Narratology is the also very often used: Zhang Guixia explored the narrator and the implied author in this novel [44] and Wei Yan summarized three characteristics of Post-modern narrative embodied in this novel [45]. Space theory is also used during this period, for example, Kang Yanhua analyzed the social space and Holden's “ideal space" in this novel [46]. Zhou Xinmin compared Salinger and $\mathrm{Su}$ Tong, a famous Chinese realistic writer [47], and Zeng Xiangyi explored Zen in this novel [48]. Since 2010, the application of such theories as ecological criticism and new historicism has brought a wider spectrum to Chinese Salinger studies.

In addition to the boil of the studies of The Catcher in the Rye, researches on Salinger's short works are also simmering. Religious elements and eastern thought are the two aspects that are paid the most attention to: $\mathrm{Xu}$ Yanqiang believed that Salinger's writing is greatly influenced by Buddhism [49] and Fang Dingjian argued that Salinger has a deep understanding of both Buddhism and Chinese Taoism [50]. Character analysis is also much welcomed by critics, for instance, Luo $\mathrm{Yu}$ thought that Teddy and Franny are both representatives of counterculture [51]; Jiang Tianping applied the power theory to analyze "the mad men" in Salinger's works [52]. What's more, the interpretation of theme can also be seen in Chinese Salinger studies at this time: Que Linghua claimed Nine Stories is basically a collection of "anti-Bildungsroman" [53]; Shang Xiaojin thought the common themes shared by The Catcher in the Rye and Nine Stories are the spiritual crisis of the protagonists and their attempt to redeem themselves [54].

All in all, studies on Salinger's short stories in China are far behind those on The Catcher in the Rye in view of the very limited number of outcomes. So far, the 22 uncollected short stories of Salinger have never been touched in China partly because of the difficult access to the texts. 


\section{CONCLUSION}

To sum up, Salinger studies in North America and in China have achieved a lot since the 1950s. Multiple perspectives lay a solid foundation for future studies. However, there are still some blanks that can be filled in the future:

First, most studies revolve around The Catcher in the Rye, Nine Stories, Franny and Zooey, Raise High the Roofbeams, Carpenters and Seymore: An Introduction, and Hapworth 16, 1924, while the other 21 uncollected short stories have barely been touched, except for one dissertation; while in China, no paper has studied those uncollected short stories at all, and the lack of proper introduction and translation of these stories is also an important reason for the shortage of relevant research.

Second, as for the eastern thought reflected in Salinger's works, Buddhism and Hinduism are talked about the most; while Taoism, one of the greatest heritages the ancient China left behind, has only been explored by several scholars. Therefore, more systematic research is needed to find out how Taoism influenced Salinger's writing, toward which, for sure, the Chinese researchers could do more.

Third, biography and epistle studies are not enough, yet. In America, Paul Alexander and Kenneth Slawenski have written biographies for Salinger; but in China, no effort has been made. In addition, book-length study is rare while short papers and repetitious studies are often seen, which means there is still much to do for a greater prosperity in China's Salinger studies.

\section{REFERENCES}

[1] A. Heiserman, and J. E. Miller, Jr. "J. D. Salinger: some crazy cliff," in Critical Essays on Salinger's The Catcher in the Rye, Joel Salzberg, Ed. Boston, MA: G. K. Hall \& Co, 1990, pp. 32-39.

[2] J. C. Unrue, Literary Masterpieces Vol.16: The Catcher in the Rye. Farmington Hills, MI: Gale Group, 2001, p. 71.

[3] I. Hassan, Radical Innocence: Studies in the Contemporary American Novel. Princeton, NJ: Princeton UP, 1973, p. 262.

[4] J. Baumbach, "The saint as a young man: a reappraisal of The Catcher in the Rye," in Critical Essays on Salinger's The Catcher in the Rye, Joel Salzberg, Ed. Boston, MA: G. K. Hall \& Co, 1990, pp. 55-64.

[5] P. J. Seng, "The fallen idol: the immature world of Holden Caulfield," College English, vol. 32, pp. 203-209, December 1961.

[6] J. R. Sublette, J.D. Salinger: An Annotated Bibliography, 1938-1981. New York \& London: Garland Publishing, Inc., 1984, pp. 168-179.

[7] D. P. Costello, "The language of The Catcher in the Rye," American Speech, vol. 34, pp. 172-181, October 1959.

[8] Ernest Jones, "Case history of all of us," Nation, vol. 173, p. 176, September 1951.

[9] E. Alsen, A Reader's Guide to J.D. Salinger. Westport, CT: Greenwood Press, 2002, p. 54.

[10] L. R. Furst, “Dostoyevsky's Notes from Underground and Salinger's The Catcher in the Rye," Canadian Review of Comparative Literature, vol. 5, pp. 72-85, Winter 1978.

[11] J. R. Sublette, J.D. Salinger: An Annotated Bibliography, 1938-1981. New York \& London: Garland Publishing, Inc., 1984, p.182
[12] J. Bryan, "The psychological structure of The Catcher in the Rye." in Critical Essays on Salinger's The Catcher in the Rye, Joel Salzberg, Ed. Boston, MA: G. K. Hall \& Co, 1990, pp. 101-16.

[13] C. Ohmann, and R. Ohmann. "Reviewers, critics, and The Catcher in the Rye," Critical Inquiry, vol. 3, pp. 15-37, Autumn 1976.

[14] G. Rosen, "A retrospective look at The Catcher in the Rye," American Quarterly, vol. 29, pp. 547-562, Winter 1977.

[15] J. C. Unrue, Literary Masterpieces Vol.16: The Catcher in the Rye. Detroit, MI: Gale Group, 2001, p. 81.

[16] S. I. Bellman, "New light on Seymour's suicide: Salinger's "Hapworth 16, 1924," Studies in Short Fiction, vol. 3, pp. 348-351, Spring 1966.

[17] M. F. Schulz, "Epilogue to 'Seymour: An Introduction': Salinger and crisis of consciousness," Studies in Short Fiction, vol. 5, pp. 128-138, Winter 1968.

[18] S. Paniker, The Influence of Eastern Thought on "Teddy" and the Seymour Glass Stories of J. D. Salinger. Austin, Texas: University of Texas at Austin, 1971.

[19] J. F. Cotter, "Religious symbols in Salinger's shorter fiction," Studies in Short Fiction, vol. 15, pp. 121-132, Spring 1978.

[20] B. Goldstein, and S. Goldstein, "Zen and Salinger, " Modern Fiction Studies, vol. 12, pp. 313-324, Fall 1966.

[21] J. C. Unrue, Literary Masterpieces Vol.16: The Catcher in the Rye. Detroit, MI: Gale Group, 2001, p. 85.

[22] ---, Literary Masterpieces Vol.16: The Catcher in the Rye. Detroit, MI: Gale Group, 2001, p. 86.

[23] A. Kaufman, “'Along this road goes no one': Salinger's 'Teddy' and the failure of love," Studies in Short Fiction, vol. 35, pp. 129-140, Spring 1998.

[24] S. O'Hearn, The Development of Seymour Glass as a Figure of Hope in the Fiction of J. D. Salinger. Hamilton, Ontario: McMaster University, 1982.

[25] A. L. Goad, The Zen Truth in J. D. Salinger: "It's very hard to meditate and live a spiritual life in America". Kirkville, MO: Northeast Missouri State University, 1995.

[26] E. D. Antonio, The Fiction of J. D. Salinger: A Search Through Taoism. Tallahassee. FL: Florida State University, 1991.

[27] B. N. Hindin, Death and the Imaginative Vision of Modern and PostModern American Fiction. Philadelphia, PA: University of Pennsylvania, 1981.

[28] J. Timberlake, Examined, Cracked, Changed, Made new: Conversion Themes and Structures in American Short Fiction. Cincinnati, Ohio: University of Cincinnati, 1995.

[29] W. F. Rannals, Narrative Voice and Authorial Intention in The Catcher in the Rye. Anchorage, AK: University of Alaska Anchorage, 2011.

[30] M. Gehlawat, "Desperately seeking singularity in Franny and Zooey"' Literature Interpretation Theory, vol. 22, pp. 59-77, February 2011.

[31] E. Demler, The Modern Identity Quest: Five Alienated Heroes of J. D. Salinger. Los Angeles, CA: California State University, 2001.

[32] E. Kilicci, J. D. Salinger's Characters as Existential Heroes: Encountering 1950s America. Indianna, PA: Indiana University of Pennsylvania, 2008.

[33] J. E. Judlin, J. D. Salinger and the Trauma of the Second World War. Kirksville, MO: Truman State University, 2015.

[34] K. R. Tolchin, Part Blood, Part Ketchup: Coming of Age in America with J. D. Salinger, Philip Roth, John Irving, Edith Wharton and Jamaica Kincaid. Boston, MA: Brandeis University, 2000.

[35] T. P. Durkin, The Games Men Play: Madness and Masculinity in Post-World War II American Fiction, 1946-64. Milwaukee, WI: Marquette University, 2007.

[36] Z. Li, "Escape and rebellion-a review of Salinger's The Catcher in the Rye," Foreign Literature Studies 3, pp. 120-121, August 1997.

[37] G. Zhang, "The study of The Catcher in the Rye in China," Journal of Zhengzhou University, vol. 37, p. 158, October 2004. 
[38] W. Hou, "The perfect combination of individuality and typicalityreview of the linguistic features in The Catcher in the Rye." Journal of Foreign Languages 5, pp. 28-34, October 1982.

[39] Z. Li, "On the linguistic features of The Catcher in the Rye, " Foreign Languages Research 4, pp.22-26, November 1994.

[40] S. Luo, "On the couner-cultural language in The Catcher in the Rye," Foreign Literature Review 1, pp. 58-60, February 1994.

[41] J. Liu, "Two lonely souls-a comparative study of Quentin and Holden," Journal of North China Electric Power University (Social Sciences) 1, pp. 58-62, January 1999.

[42] S. Cao, "Esme - the ideal personality of Salinger," Foreign Literatures 3, pp. 106-110, August 1996.

[43] Z. Yan, "The Catcher in the Rye: deterritorialization and reterritorialization of cultural codes," Foreign Literature Studies 2, pp. 23-26, May 1999.

[44] G. Zhang, "The narrator and the implicit author of 'The Catcher in the Rye,", Journal of Luoyang University, vol. 19, pp. 51-54, September 2004.

[45] Y. Wei, "The characteristics of postmodern narrative and its existence in Salinger's The Catcher in the Rye," Journal of Nanjing Normal University 4, pp. 126-131, August 2001.

[46] Y. Kang, A Study on The Catcher in the Rue from the Perspective of Spatial Theory. Yantai, Shandong: Ludong University, 2012.

[47] X. Zhou, "Salinger and Su Tong: the writing and creating of juvenile images," Foreign Literature Studies 3, pp. 123-130, June 2009.

[48] X. Zeng, "Zen Buddhism and the Catcher in the Rye," Journal of PLA University of Foreign Languages 1, pp. 86-90, January 2006.

[49] Y. Xu, Buddhism in the Art of J. D. Salinger. Jinan, Shandong: Shandong University, 2008.

[50] D. Fang, "Salinger and Chinese culture," Journal of Qiqihar University 4, pp. 17-19, July 2004.

[51] Y. Luo, "Salinger's road of rebellion: rrom Teddy to Zooey—review of Franny and Zooey," Book Town 3, pp. 101-103, March 2008.

[52] T. Jiang, "Madness: childness of catching the banana-fishSalinger's madman," Journal of University of South China 4, pp. 102105, August 2008.

[53] L. Que, The Sound of Solitude-Nine Stories as an AntiBildungsroman. Nanjing, Jiangsu: Nanjing Normal University, 2014.

[54] X. Shang, "Spiritual crisis and self redemption," in English and American Literary Studies. Shanghai: Shanghai Foreign Language Education Press, 2001, pp. 196-209. 